\title{
ЗНАЧАЈ И УЛОГА ТЕХНИЧКОГ ЗАКОНОДАВСТВА ЗА БЕЗБЕДНОСТ ПРОИЗВОДА НА ТРЖИШТУ
}

\section{SIGNIFICANCE AND ROLE OF TECHNICAL LEGISLATION FOR PRODUCT SAFETY ON THE MARKET}

\begin{abstract}
Драгана Вујичић, Факултет
ОбЛасТ - ИНЖЕЊЕРСТВО ЗАШТИТЕ НА РАДУ

Кратак садржај - У раду су дата основна објашюења везана за појам техничког законодавства, са посебним освртом на техничко законодавство ЕУ. Детаљно су објашьени Нови и Глобални приступ. Анализирана је инфраструктура квалитета и ниво техничког законодавства у Републищи Србији.
\end{abstract}

Кључне ријечи: техничко законодавство, очјениване усаглашености, инфраструктура квалитета.

\begin{abstract}
The paper provides basic explanations related to the concept of technical legislation, with special reference to EU technical legislation. The New and Global Approaches are explained in detail. The quality infrastructure and the state of technical legislation in the Republic of Serbia were also analyzed.
\end{abstract}

Keywords: technical legislation, conformity assessment, quality infrastructure.

\section{1. УВОД}

Унутрашње тржиште Европске Уније предстаља подручје без унутрашњх граница гдје је загарантован слободан проток људи, роба, услуга и капитала.

Да би се отклониле баријере и омогућило несметано кретање производа, ЕУ је развила низ механизама међу којима су Нови приступ у погледу правила за производе и Глобални приступ у погледу оцјењивања усаглашености.

Друго поглавље рада говори о техничком законодавству ЕУ, које је засновано на Старом приступу с једне и Новом и Глобалном приступу са друге стране. Приступи су укратко објашњени, као и улога хармонизованог стандарда.

У трећем поглављу рад говори о директивама Новог приступа, њиховој примјени и захтјевима. Глобални приступ, односно модули за оцјењивање усаглашености, описан је у четвртом поглављу.

Инфраструктура квалитета и стање националног техничког законодавства описани су у петом и шестом поглављу.

\section{НАПОМЕНА:}

Овај рад проистекао је из мастер рада чији ментор је био проф. др Миленко Секулић.
Рад говори о проблемима постојећег националног законодавства, као и циљевима развоја националне инфраструктуре квалитета.

У последњем поглављу дата су закључна разматрања и осврт на значајне дијелове, а након тога дата је литература рада.

\section{2. ТЕХНИЧКО ЗАКОНОДАВСТВО ЕВРОПСКЕ УНИЈЕ}

Техничко законодавство Европске Уније засновано је на општем шематизованом приступу (директиве Новог и Глобалног приступа) и на секторском приступу (Стари приступ).

Шематски приступ се заснива на безбједности производа, односно дефинисању захтјева за заштиту живота, здравља, околине и потрошача садржаних у директивама Новог приступа.

Директиве Новог приступа прате хармонизовани стандарди, којим се дефинишу сви остали захтјеви за производе.

\section{1 Стари приступ}

Директиве Старог приступа детаљно прописују основне и остале захтјеве, које треба да испуњавају производи. Производи који су покривени директивама Старог приступа су:

- моторна возила и приколице,

- моторна возила са два или три точка,

- прехрамбени производи,

- хемијски производи,

- лијекови за људску употребу,

- лијекови за ветеринарску употребу.

\section{2 Нови приступ}

Године 1985. Савјет ЕУ успоставља Резолуцију о Новом приступу техничкој хармонизацији и стандардизацији. Директиве Новог приступа засноване су на утврђивању битних безбједносних и здравствених захтјева за људе и животиње, затим на захтјеве животне средине и за велике групе производа.

\section{3 Глобални приступ}

Године 1989. Резолуцијом вијећа ЕУ усвојен је Глобални приступ оијењивању усаглашености, који обезбјеђује процедуру оцјењивања усаглашености и институцију независног овлашћеног органа, који исту спроводи. 


\section{4 Улога хармонизованог стандарада}

Европски стандарди дефинисани су Директивом 98/34/ЕС као техничке спецификације усвојене од европских организација за стандардизацију. Тренутно постоје три европске организације за стандардизацију, које су признате у овкиру Директиве:

- CEN - Европски комитет за стандардизацију,

- CENELEC - Европски комитет за стандардизацију у електротехници,

- ETSI - Европски институт за стандарде у подручју телекомуникација.

\subsection{1 Претпоставка о усаглашености}

Претпоставка о усаглашености са одговарајућим битним захтјевима обезбијеђена је од стране хармонизованих стандарда, ако се њихови основни подаци објаве у Службеном гласнику ЕУ и ако су преузети на националном нивоу, али не обавезно у свим земљама чланицама.

\subsection{2 Ревизија хармонизованих стандарда}

Европско тијело за стандарде доноси одлуку о ревидирању стандарда. Потреба за ревизијом може се појавити из промјене подручја примјене одређене директиве или ако држава чланица или Комисија испитује садржаје хармонизованог стандарда при том дајући индикацију да он не би могао даље обезбјеђивати претпоставку о усаглашености са битним захтјевима.

\section{3. ДИРЕКТИВЕ НОВОГ ПРИСТУПА}

Од 1987. године усвојено је укупно 25 директива на основу Новог и Глобалног приступа. Ови законски акти сматрају се најважнијим законским инструментима за успостављање и јачање унутрашњег тржишта EУ.

\section{1 Примјена директива Новог приступа}

Неки од производа на које се односе директиве Новог приступа су:

- нисконапонска опрема,

- играчке,

- машине

- грађевински производи,

- лична заштитна средства,

- медицински уређаји,

- мјерни инструменти,

- поморска опрема,

- амбалажа и амбалажни отпад.

Неопходно је нагласити да се директиве примјењују само када се производ први пут пласира на тржиште ЕУ. Зато се директиве примјењују на коришћене и половне производе, који су увезени из трећих земаља када улазе на тржиште први пут, али се не примјењују на такве производе који су већ на тржишту.

\section{2 Захтјеви директива Новог приступа}

Производи, када су усаглашени са захтјевима одговарајућих директива означавају се СЕ ознаком. Постоји 21 директива Новог приступа којима се захтијева означавање производа СЕ ознаком, док 4 директиве не обавезују означавање. Важи правило да државе не смију уводити ни оштрије ни блаже мјере од оних које су предвиђене у директивама

\section{3 Директива за машине 2006/42 ЕС}

Директива за машине 2006/42/EC дефинише основне безбједносне захтјеве, који морају да се узму у обзир приликом пројектовања, конструисања и производње машина.

EC

\subsection{1 Примјена Директиве за машине 2006/42}

Директивом су обухваћени сљедећи производи:

- машине,

- замјенљива опрема,

- безбједносне компоненте,

- прибори за подизање,

- ланци, конопци и траке,

- монтажно-демонтажни механички преносни уређаји.

Стављање машине на тржиште и пуштање у потребу дефинисано је бројним обавезама везаним за састављање упутстава за рад машине, ЕЦ Изјава о усаглашености и начин означавања СЕ ознаком.

\subsection{2 Поступци за утврђивање усаглашености машине}

Уколико машина није наведена у Прилогу IV, произвођач или његов овлашћени представник примјењује поступак за оцјењивање усаглашености интерним провјерама производње машине.

Ако је машина наведена у Прилогу IV и притом произведена у складу са хармонизованим стандардима који покривају одговарајуће битне захтјеве, произвођач или овлашћени представник примјењује један од сљедећих поступака:

- поступак за оцјењивање усаглашености интерним провјерама производње,

- поступак ЕЦ испитивања типа и интерним провјерама производње,

- поступак потпуног обезбјеђивања квалитета.

Када машина наведена у Прилогу IV није произведена у складу са хармонизованим стандардима или је само дјелимично у складу са њима, или ако хармонизовани стандарди не обухватају све одговарајуће битне захтјеве или ако не постоје хармонизовани стандарди за одређену машину, произвођач или овлашћени представник примјењује један од сљедећих поступака:

- поступак ЕЦ испитивања типа и интерне провјере производње,

- поступак потпуног обезбјеђења квалитета.

\subsection{2 Хармонизовани стандарди обухваћени}

\section{Директивом за машине 2006/42/EC}

Хармонизовани стандарди обухваћени МД по садржају и значају дијеле се у три типа, а приказани су на слици 5:

- тип А: основни стандарди безбједности машина,

- тип Б: групни стандарди безбједности,

- тип Ц: стандарди безбједности производа. 


\subsection{3 Оцјена ризика у Директиви за машине 2006/42/EC}

Произвођач или овлашћени представник има обавезу да идентификује све ризике од машине.

Уколико су ризици покривени хармонизованим европским стандардима, нема даљих активности за те ризике. За остале ризике, неопходно је урадити анализу ризика и смањити ризике у фази пројектовања машине. У обзир се узимају резултати оцјене ризика приликом пројектовања и конструисања машине.

\section{4. ПРОЦЕДУРЕ ОЦЈЕЊИВАЊА УСАГЛАШЕНОСТИ ПРОИЗВОДА}

Директиве дефинишу, осим битних захтјева за све производе и специфичних за одређене групе производа, одговарајуће процедуре оцјењивања усаглашености у складу са Глобалним приступом, као и услове које треба да задовоље тијела која врше оцјењивање усаглашености.

\section{1 Модули Глобалног приступа}

Оцјењивање усаглашености врши се преко осам основних модула: А, Б, Ц, Д, Е, Ф, Г, Х и заснива се на:

- унутрашњим контролним активностима произвођача у пројектовању и производњи,

- оцјењивању типа производа преко треће стране,

- оцјењивању типа производа преко треће стране у комбинацији са одобрењем производа или система менаџмента квалитетом,

- верификацији производа преко треће стране,

- одобрењу цјелокупног система менаџмента квалитетом од треће стране.

\section{2 Стадандард система квалитета ISO 9000}

ISO 9000 серија међународних стандарда управљања квалитетом представља основу у глобалу за успостављање ефективног и ефикасног система управљања квалитетом. Све организације дјелују у глобалној економији, продајом или куповином производа и услуга ван домаћег тржишта, па отуда потреба за међународним стандардима.

\section{3 Сертификат о ЕЦ испитивању типа и ЕЦ изјава о усаглашености}

ЕЦ изјава о усаглашености мора да докаже да производ задовољава одређене битне захтјеве директива које се примјењују или да је производ усаглашен са типом за који је издат сертификат о ЕЦ испитивању типа и да су задовољени битни захтјеви поменутих директива.

\section{4 Овлашћена тијела за оцјењивање усаглашености}

Овлашћена тијела се именују да би оцијенили усаглашеност са битним захтјевима и осигурали правилну примјену техничких захтјева, у складу са директивама. Она представљају трећу страну, која је независна о својим клијентима и осталим заинтересованим странама.

\section{5 Означавање производа СЕ знаком}

CE означавање представља једино означавање којим се потврђује да су производи усаглашени са директивама које се заснивају на Глобалном приступу. Производ, који носи СЕ знак, усаглашен је са битним захтјевима, који се односе на безбједност, опште здравље, заштиту потрошача/корисника.

\section{5. ИНФРАСТРУКТУРА КВАЛИТЕТА}

Инфраструктура квалитета обухвата више компоненти, који чине тзв. Европску кућу квалитета, а то cy:

- стандардизација,

- акредитација

- метрологија,

- оцјењивање усаглашености (испитивање, еталонирање, контролисање и сертификација),

- квалитет са надзором тржишта.

\section{1 Стандардизација}

Стандарде доносе међународне организације или национална тијела за стандардизацију и садрже правила, захтјеве, упутства, карактеристике, препоруке или смјернице за активности или њихове резултате у циљу постизања оптималног нивоа уређености у одређеној области.

\section{2 Акредитација}

Акредитација представља поступак утврђивања компетентности тијела за оцјењивање усаглашености.

\section{3 Метрологија}

Метрологија обезбјеђује сигурност у тачност резултата мјерења. То се постиже употребом тачних мјерила,која су усаглашена са захтјевима утврђеним на међународном нивоу.

\section{4 Оцјењивање усаглашености}

Оцјењивање усаглашености представља поступак, којим се доказује да су испуњени специфични захтјеви који се односе на производ, као и захтјеве одређеног стандарда.

\section{5 Надзор над тржиштем}

Тржишни надзор представља многе активности од стране државних органа у циљу постизања усаглашености производа са одређеним захтјевима, односно спрјечавања да производ угрози здравље, безбједност или неки други облик јавног интереса.

\section{6. АКТУЕЛНО СТАЫЕ ТЕХНИЧКОГ ЗАКОНОДАВСТВА У РЕПУБЛИЦИ СРБИЈИ}

Процес хармонизације националног техничког законодавства са техничким законодавством ЕУ започет је 2005. године. Значајнији резултати остварени су у 2009. и 2010. години када је донијет низ закона из подручја инфраструктуре квалитета.

\section{1 Хоризонтални правни оквир инфраструктуре квалитета}

Хоризонтални правни оквир инфраструктуе квалитета у Р. Србији успостављен је доношењем четири закона и подзаконских аката из области техничких захтјева 
за производе и оцјењивање усаглашености, стандардизације, метрологије и акредитације.

\section{2 Технички прописи у Републици Србији}

Постоје двије основне групе техничких прописа:

- технички прописи којима се преузима европско техничко законодавство, а прије свега директиве и уредбе Старог и Новог приступа и

- српски изворни технички прописи.

2009. године спроведен је Акциони план за израду техничких прописа са мјерама за њихову примјену.

\section{3 Проблеми у развоју националне инфрастурктуре квалитета}

Постоји проблем у областима, гдје не постоје акредитована тијела за оцјењивање усаглашености јер је акредитација добровољна. Занемарују се обавезе прибављања домаћих исправа и српског знака усаглашености при пласирању производа на домаће тржиште, претпостављајући да је он сувишан код производа означених СЕ знаком.

\section{4 Стратешки циљеви развоја националне инфраструктуре квалитета}

У циљу развоја инфраструктуе квалитета потребно је ојачати капацитете органа државне ураве и регулаторних тијела која доносе техничке прописе.

Ово се може постићи унапређењем, као и образовањем нових организационих јединица, које ће бити задужене за припрему и примјену техничких прописа, као и јединице за утврђивање компетентности тијела за оцјењивање усаглашености за спровођење прописаних поступака оцјењивања усаглашености.

\section{7. ЗАКЉУЧАК}

За разлику од Старог приступа, филозофија Новог приступа подразумијева да се европским директивама дефинишу само битни захтјеви за безбједност производа, а да се детаљан технички садржај налази у хармонизованим европским стандардима.
Оцјењивање усаглашености засновано је на Глобалном приступу, односно модулима за оцјењивање усаглашености. За разлику од Старог приступа, усаглашеност са захтјевима директива потврђује сам произвођач - декларацијом о усаглашености или исправом о усаглашености коју издаје именовано тијело за оцјењивање усаглашености.

\section{8. ЛИТЕРАТУРА}

[1] Јовишевић В, Боројевић С, 2010, Стандардизација и индустријска легислатива, Бања Лука

[2] Митровић Р, Поповић П, 2009, Оцењивање усаглашености производа - развој инфраструктуре, Београд

[3] Стратегија унапређења система инфраструктуре квалитета у Републици Србији за период 2015-2020. године

[4] Поповић П, Митровић Р, Јелић М, 2011, Развој националне инфраструктуре квалитета, Београд

[5] Поповић П, 2010, Акредитација и оцењивање усаглашености, Београд

\section{Кратка биографија:}

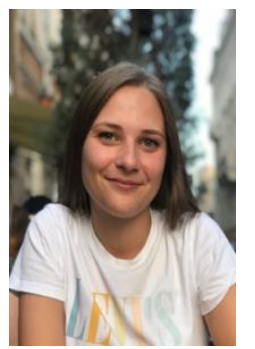

Драгана Вујичић рођена је у Инзбруку 1996. године. У Дервенти је завршила Гимназију „Михајло Пупин“. Дипломирала је 2019. године на Факултету техничких наука у Новом Саду, смјер инжењерство заштите животне средине. Мастер рад на смјеру инжењерства заштите на раду одбранила је 2021. године. 